\title{
Assessment Transformation of Labor Relations and their Regulation in Insurance
}

\author{
Selivanova M.A.* \\ Financial University under the Government \\ of the Russian Federation \\ Moscow, Russia \\ e-mail: marishka6891@mail.ru
}

Ilinykh Yu.M.

Financial University under the Government of the Russian Federation, Altai branch

Barnaul, Russia

e-mail: yulia-iln@mail.ru

\author{
Pirogova T.V. \\ Financial University under the Government \\ of the Russian Federation, Altai branch \\ Barnaul, Russia \\ e-mail: pirogowa@yandex.ru
}

\author{
Kolyada N.I. \\ Financial University under the Government of the Russian \\ Federation, Altai branch \\ Barnaul, Russia \\ e-mail: nikolai59115@mail.ru
}

Abstract - The article is devoted to the transformation of labor relations in insurance activity in the conditions of digital economy. The growth of electronic commerce is going to continue in the nearest future and certain changes in labor legislation will become a necessity. The information about an employee's labor activities is centralized based on their increasing labor opportunities and convenience of statistical measurement for an employer. At the same time digitalization of labor relations will make existing social problems in the society rather acute. Digitalization is noted to affect unemployment level, remuneration and complexity of work in the insurance sphere. The elements of interaction between Russia and international organizations on issues of professional relations and their development in the insurance sphere are also considered. It is easy to notice the influence of digitalization on the state of traditional social production spheres and employment level in traditional industries. Specific features of development in insurance activity in separate regions, Moscow and St. Petersburg are presented in the article too. The article contains the analysis of insurance market development and demand for vacancies on the insurance market in the Russian Federation. The changes in structure of insurance products on offer and their complexity growth are also stated. The above-mentioned points raise the problem of inefficient training of insurance employees who do meet the requirements of modern market. They must be provided with further training aimed at improvement of their professional skills and quality of service to a modern customer. The level of modern labor relations development makes it necessary for every employee to perform many operations in conditions of multitasking. This makes clear that demand for knowledge of new technologies is constantly increasing. In this regard the article contains proposals for improving competences of specialists in insurance companies. That is why what emerges is the need for incentives for insurance workers when they improve their qualifications. The article also underlines the problem of employees' skills improvement since complexity of insurance market products grows.

Keywords - insurance market, digitalization, competences, innovation services, distant employment, professional standards.

\section{INTRODUCTION}

Technological revolutions accompany all human history. They appear as phenomena leading to creation and development of completely new technologies, which change not only a technological lifestyle but the society itself. As a result social and economic development of the society changes to a new quality level.

Introduction of modern technologies into human life causes disappearance of many professions and emergence of new ones. In turn it becomes a trigger for creating absolutely new types of labor which meet the requirements of arising technological lifestyle.

Nowadays people operate in a new working environment which is considered as a new form of employment. Transformation of labor relations concerns Russia too, where distant employment, employment on online platforms, crowdworking, etc. are already widely available. These forms of employment require solving problems relating to technical aspects of labor organization and protection of employees' labor rights. The documents of program implications are adopted in Russia; labor-related laws are updated and adapted to the new forms of employment.

The tendency of information society development existing in the world today proposes to revise the current model of production factors including land, capital and labor and introduce the 5-th factor - information [1;2] as minimum. The programs for the development of digitalization announced in Russia and rapid establishment of the digital society require a different approach to training and re-training all categories of population including insurance activity.

\section{RESULTS AND DISCUSSION}

The program "The Digital Economy of the Russian Federation" adopted in Russia defines the conception of digital economy in terms of economic activity with the data in digital form as the key factor. 
In 2018 the contribution of digitalization in Russian economy amounted to $5.1 \%$ of GDP that is higher than in 2017 - the average annual increase rate is 10-15\% [3]. Figure 1 shows the e-commerce performance in Russia with an outlook for 2019.

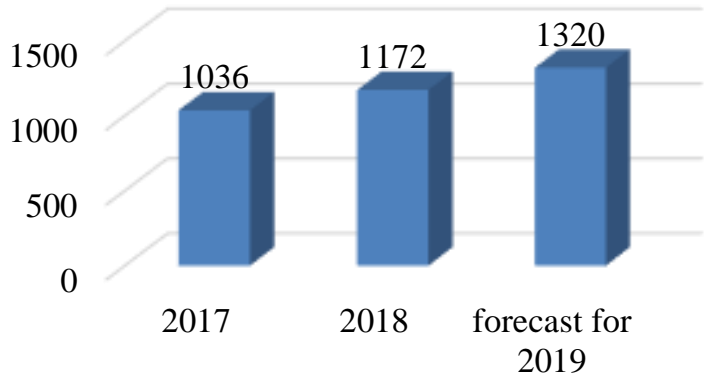

Fig. 1. E-commerce performance of Russia in 2017-2018 and outlook for 2019 , trillion rubles [3]

According to the information provided the increase in Russian e-commerce in 2017-2018 amounted to $13 \%$ and analysts forecast that this tendency is going to continue in the nearest years. Important contribution to the development of this market segment was made by online merchants engaged in business development in regions. These figures demonstrate significant market changes.

Digitalization entails changes in all levels of governance. This will first affect social and labor relations. Practices in regulating labor relations are based on the use of common and specific principles depending on changes in the situation at a certain period of time. Specific principles often result in application of fundamentally new models when building labor relations.

Among the main changes in labor legislation in the Russian Federation in 2019 are the following:

- introduction of clause 49.1 "Special Features Regulating Employment of Distant Employees" which defines non-standard employment (distant labor) [8];

- planned transition to electronic employment record books. The Ministry of Labor in Russia is planning to introduce an electronic employment record book [9].

Beginning with January 1, 2020 employers will send their employee's working history to the Russian Pension Fund [6]. This digital format will provide people with convenient and quick access to the information about their employment activity. Employers will also get new opportunities for human resources records. It should be underlined that transition to electronic employment record books for citizens remains voluntary except those who will start their labor activity in 2021.

Today the transition to electronic employment record books is voluntary.

There are some new notions besides the concept of "Electronic employment record book":
- personnel document management in electronic format: recruitment and dismissal from employment, transfers, provision of holidays, attendance records, familiarization with local regulations, notifications of different nature, etc.;

- electronic surveillance - interaction between an employer and Labor Inspectorate, reviews from citizens' appeals.

International organizations find it puzzling that digitalization has been projected to lead to rapid increase of inequality among people in the nearest 50 years. In order to ensure further development of innovations, productivity and labor market expansion it is necessary to carry out reforms in the sphere of labor relations and to take effective measures to improve governance in the educational sphere. It will allow satisfying growing demand for skills [7].

It is important to note that labor market changes in digitalization environment will enhance the magnitude of social problems in society since the effective performance of a concrete employee causes unemployment increase and differentiation in the pattern of remuneration.

Regulation of labor relations at the international level is implemented through the documents of the International Labor Organization enshrining fundamental human rights and relations connected with the sphere of employment, social welfare and employees' rights.

According to these documents the major principle is social cooperation, built on contractual arrangements or system of agreements. Peculiarities of labor relations regulation in various fields differ according to specific nature of influence of external and internal environmental factors. They provide the basis for regulating the management of labor relations.

The Program of Cooperation between Russia and the International Labor Organization for 2017-2020 envisages the following key directions to develop labor relations:

1. Increasing employment of population with simultaneous productivity growth.

2. Observance of labor standards and conditions.

3. Expansion of relations in the field of social insurance and pension system

\section{Dissemination of international labor standards.}

Digitalization in developed and some developing countries causes reduction and stagnation in the "old" fields of economy. The main distinction of Russia lies in the fact that the development of modern economy lines takes place against the background of elimination of the productive economic base accumulated by previous generations. It results in development restraint of both new economy and nature of employment in it. Thus, from 2013 to 2017 the proportion of the employed in $\mathrm{Z}$ and $\mathrm{Y}$ generation in the general employment structure was reduced from 49,3 to $48,8 \%$ [11]. But in financial and insurance activities employment growth continued in those 5 years and made up $3 \%$ with an outlook for stagnation [11]. 
It needs to be stressed that though the total number of employees engaged in financial and insurance activities has remained the same in recent years, the structure of the demand for employees in these fields is changing. The demand on highly skilled personnel such as investors, financers, real estate surveyors, etc. is rapidly growing. Insurance workers must be equipped with the appropriate skills and competences typical for insurance activities in risk management system and insurance supervisory authorities. It is this specificity of activity that determines training of personnel for insurance business.

The Russian insurance labor market depends on the development of insurance sector of the country (Table 1). There is a vivid tendency of decrease of insurance companies on the market in recent years. Their number has declined twofold over the past three years.

At the same time insurance market itself continued to develop and its growth in 2018 made up $15.7 \%$. Demand for individual credits caused the volume increase of insurance against accidents, illness and automobile insurance. In 2018 insurers made substantial profits which were 1.5 times higher than in 2017. The increase of income was due to the growth of profits from investment activities and also the decrease of loss -making.

The growth of insurance premiums in 2018 was $2.5 \%$, their amount exceeded 522 billion rubles. Life insurance premiums grew by $14.9 \%$. It was caused by the increase of investment life insurance premiums due to the cut-of-date of insurance products purchased 3-5 years earlier.

TABLE I. MAIN INDICATORS OF RUSSIAN INSURANCE BUSINESS [14]

\begin{tabular}{|l|l|l|l|l|}
\hline \multicolumn{1}{|c|}{ Market indicators } & $\mathbf{2 0 1 6}$ & $\mathbf{2 0 1 7}$ & $\mathbf{2 0 1 8}$ & $\begin{array}{c}\mathbf{2}^{\text {nd }} \text { semester of } \\
\mathbf{2 0 1 9}\end{array}$ \\
\hline $\begin{array}{l}\text { Number of insurance } \\
\text { companies }\end{array}$ & 376 & 226 & 199 & 188 \\
\hline $\begin{array}{l}\text { Insurance premiums, } \\
\text { trillion rubles }\end{array}$ & 1.2 & 1.3 & 1.5 & 0.74 \\
\hline $\begin{array}{l}\text { Insurance premiums, } \\
\text { billion rubles }\end{array}$ & 505.8 & 509.7 & 522 & 285.9 \\
\hline $\begin{array}{l}\text { Insurance premiums } \\
\text { per person, thousand } \\
\text { rubles }\end{array}$ & 8.1 & 8.7 & 10.1 & \\
\hline $\begin{array}{l}\text { Insurance premiums to } \\
\text { GDP }\end{array}$ & 1.37 & 1.39 & 1.43 & 1.4 \\
\hline
\end{tabular}

In the second half of 2019 the number of insurance companies fell by 11 to 188 while the number of insurance brokers rose to 68 [14].

The Online Monitoring system of Russian labor market of the recruiting agency "HeadHunter" made it possible to analyze changes in the total number of vacancies in the insurance segment of Russia in all federal regions during 2018.

The data shown in figure 3 present a dramatic decline of the vacancy number in the Russian insurance segment in federal regions with the greatest fall in the North-Caucasus region $(57 \%)$. It is connected with low income of population and, as a result, low insurance density compared with other Russian regions. On the whole one can see a downward trend of insurers (mainly regional companies).

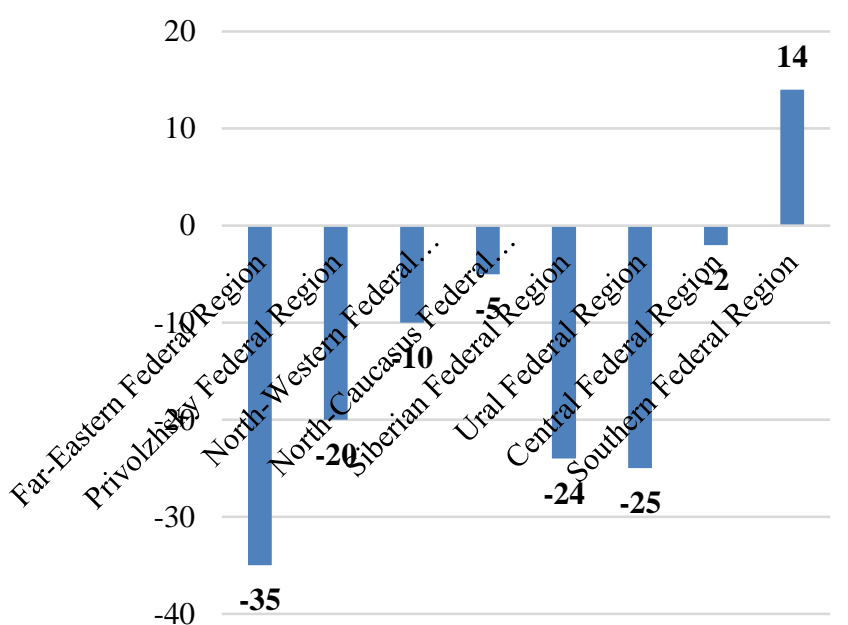

Fig. 2. Trends in changes of a number of vacancies in Russian insurance segment in federal regions from August 2018 to August 2019, \% [15]

Likewise, the number of specialists in insurance companies demonstrating growth since 2000s has started to decline. It is in line with general trends in the companies on financial market.

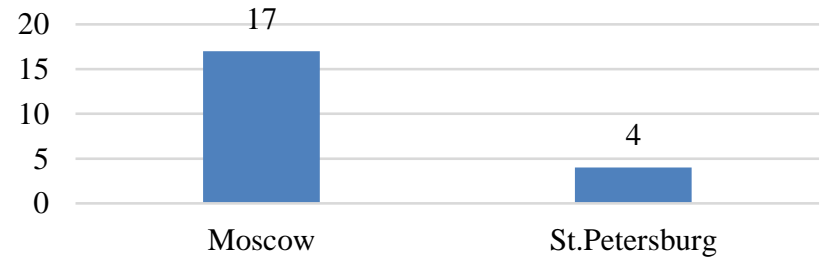

Fig. 3. Trends in changes of a number of vacancies in insurance segment, Moscow and St. Petersburg, from August 2018 to August 2019, \% [15]

Considering the data in figure 4 it can be stated that the situation on the labor market in Moscow and St Petersburg insurance segment differs from the situation in other regions. There was growth of 17 and $5 \%$, respectively, during the period under review.

"HeadHunter" agency uses Hh. Index in professional spheres. It shows the number of applicants for one vacancy at the moment

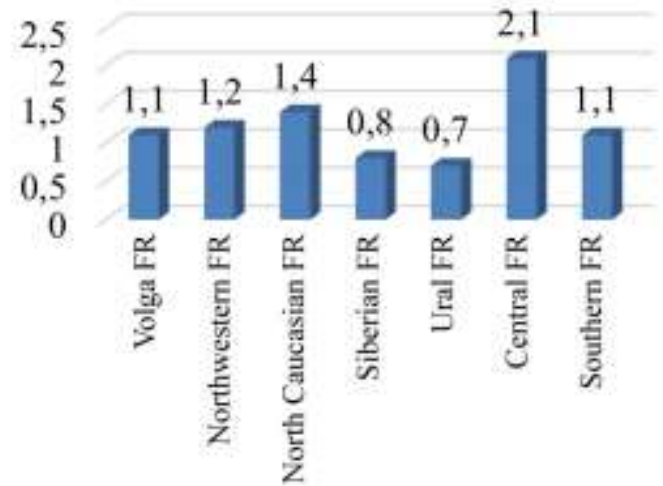

Fig. 4. Hh.index of insurance market from August 2018 to August 2019 [15] 
The data in figure 4 demonstrate that the lowest Hh. index is observed on the labor market in the Ural Federal Region, where there are more than $2 \mathrm{CVs}$ per vacancy. It is connected with high population and insurance density of the region.

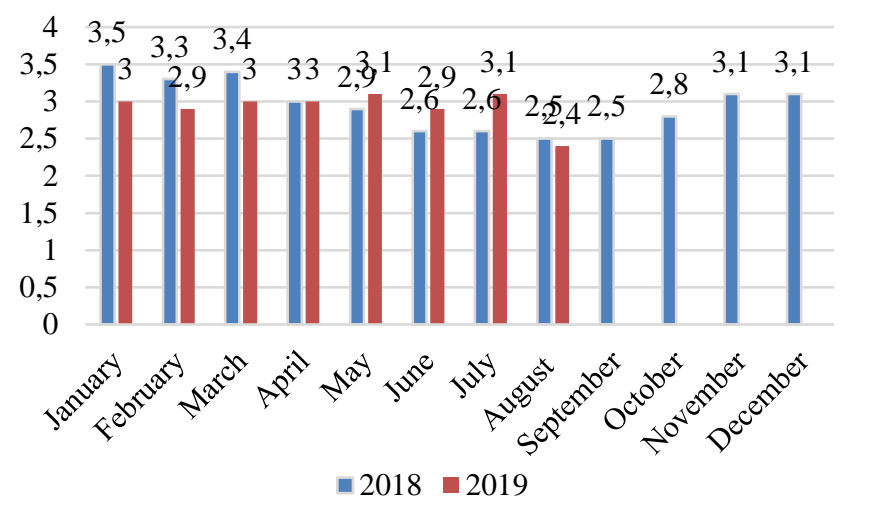

Fig. 5. Hh.index trends in insurance segment of Moscow from August 2018 to August 2019 [15]

According to the data in figure 5, Hh. index in Moscow was 2,4 in August, 2019. The index at the same period in 2018 was slightly higher -2.5 . These changes can be explained by transactions connected with mergers and acquisitions of TOP20 insurance companies (e.g. LLC IC "VTB Strahovanie" and JSC "SOGAS", open JSC "Kapital Strahovanie", closed JSC“Kapital Perestrahovanie”, JSC “Rosgosctrah”)

At the same time comparing $\mathrm{Hh}$ index data in insurance and banking segments (Figure 6), it should be stressed that competition on the labor market in banking segment is higher than in insurance one. However, there has been a steady tendency of significant job losses in credit organizations as the result of automation processes.

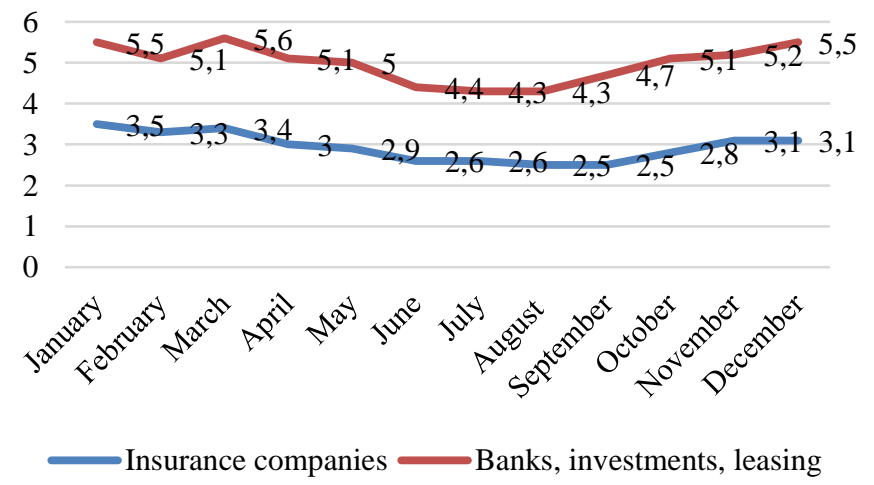

Fig. 6. Hh. index trends in insurance segment, banking sphere, investments and leasing of Moscow in 2018 [15]

This situation indicates an emerging trend of staff reductions in insurance companies while the functions of the remaining staff become more complex.

An important role in making specialists' functions complex belongs to digital technologies, namely, the artificial intelligence, robotization of business processes, multi-channel data collection, their analysis and use of instruments of behavioral economics.

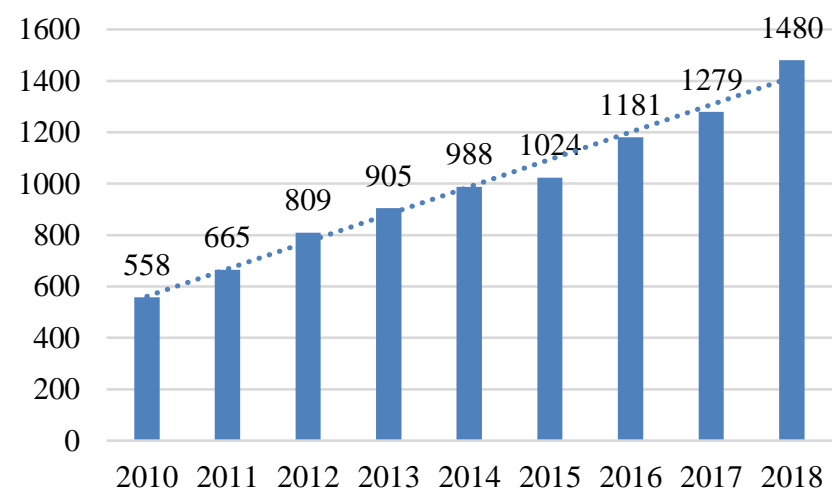

Fig. 7. Trends of insurance premiums of Russian insurance companies in 2010-2018 [14]

The data in figure 7 reflect that heavy demand on insurance companies is increasing despite all the changes. At the same time the structure of insurance market is also beginning to shift towards more complex insurance products.

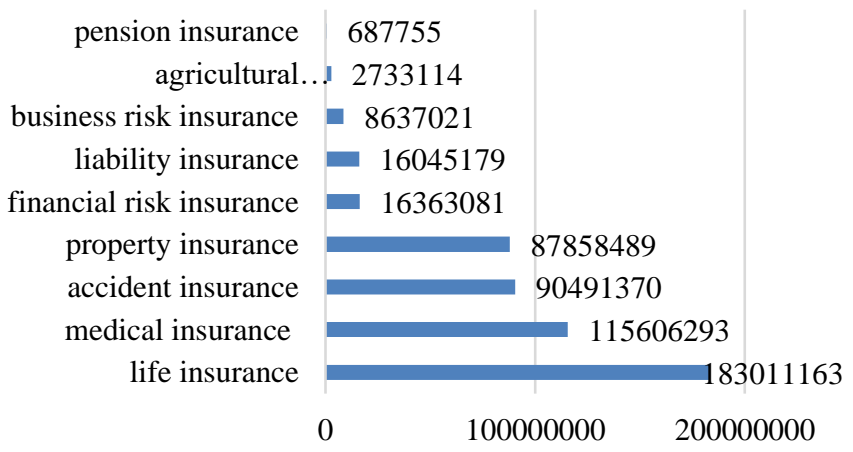

Fig. 8. Premium trend according to insurance products in the first half of 2019, thousand rubles [14]

The information on figure 8 shows that the largest volume of insurance was in life insurance market during the first half of 2019. Complex insurance products such as investment and life savings insurance remain key drivers of growth. New technological environment for the sale of insurance products requires defining and formalizing professional knowledge and practical skills of insurers. This problem can be solved with introduction of professional standards.

Professional standards are indicators to measure the level of professional knowledge for both an employee and an employer. Professional standards let insurance companies establish the basis for job instructions and universities determine areas for development of educational programs. Professional standards are primary framework based on the symbiosis of professional requirements of both educational institutions and insurance companies [16].

Accordingly, the main trend of today's Russian insurance labor market is transformation of occupations to digital technologies. It will result in reduction of jobs for low-grade specialists and growth of qualification level of professionals working in insurance companies as a consequence of their responsibilities increased by digital competences. 
Special attention should be paid to the risks connected with the gap between competences in the age of digitalization and the ones owned by current labor force. An employee working in the environment of digital economy must know how to collect and analyze complex information and adapt to it easily. They must have critical and creative thinking, make quick decisions and find the right ways to reach targets.

At this stage in the development of labor relations, it is very important for a specialist to be able to carry out many operations and work in multi-tasking environments. At the same time knowledge requirements for new technologies are constantly increasing.

Changes in social labor relations connected with digitalization of economy are reflected in an integrated approach to the development of professional standards, which are the part of National System of Qualifications regulated by article 195.3 of Labor Code of the Russian Federation [17].

It is the professional standard that gives the description of a specialist's activity. It indicates the necessity of having definite knowledge and skills. Professional standards must be regularly updated and supplemented. It leads to transformation of specialists' knowledge and skills and social-labor relations, respectively. The significant role of competence proficiency is underlined at all levels of labor relations.

Nowadays universities train insurance staff on different educational levels: baccalaureate, magistracy, postgraduate studies. Master's degree programs for training insurers are developed in accordance with Russian professional standards "Insurance Specialist" and "Insurance Broker". The qualification of Masters responds to the demands of levels 7 and 8 according to the order of the Russian Ministry of Labor of 12/04/2013 N148H "About Approval of Qualification Levels Aimed at Development of Projects of Professional Standards" and the description of a professional standard, order of the Russian Ministry of Labor № 155n "About Approval of Professional Standard "Insurance Specialist" $[18,19]$.

The digitalization process of financial markets affects insurance market as well. Increase in the proportion of young customers from $\mathrm{Z}$ and $\mathrm{Y}$ generations leads to creating fundamentally new conditions of insurance products and services. It also proposes new requirements for insurers and change of the labor relations system.

Historically, insurance has gone through some stages in introduction of innovation technologies in the industry:

- development of the current payment system;

- emergence of insurance intermediaries;

- computerization of business processes.

Insurance companies trying to keep up with the times develop and introduce innovation services allowing them to raise transaction speed and replace staff members with computer bots.

Insurers actively use mobile applications, aggregator websites, financial supermarkets to choose necessary products and sign the purchase on company website (e.g. cherehapa.ru or banki.ru)

Large-scale introduction of digital technologies into insurance activities needs to consider the specificity of regulated area and to estimate positive changes and possible risks. Digital technologies allow to raise the speed of decision making and to improve their quality.

Document constructors, joint work software, software for automatic check of documents, mobile applications, evaluation models of insurance risks, etc. are widely used in insurance business at present.

2018 was the year when the market of electronic insurance policies (excluding e-OSAGO (MTPL) grew to 6 billion rubles, the proportion of electronic polices OSAGO (MTPL) reached $50 \%$, insurance agents and aggregators started introduction of their hyperlinks in portals of government services and housing and communal services.

Insurance companies try to stop using printed forms intending to reduce costs on printing, remuneration and logistics. They are ready to design polices in electronic form and develop electronic insurance market. All this proves that transformation of insurance market and labor relations on it is taking place.

In this regard, a specialist of an insurance company faces the challenge to acquire new competences, that will help them develop big data processing skills, quickly identify problems, model and estimate risks, calculate the effect of proposed regulatory solutions, etc.

Based on insurance market research, $37 \%$ of insurance companies in Russia evaluate the level of digitalization of more than $30 \%$. Most insurance companies use the technology of "business-processes" in their activities. However, less than a half companies apply technologies connected with big amounts of data, only $30 \%$ of insurers address to the technology of the artificial intelligence.

Analyzing labor market in the insurance industry one can note a positive trend in the development of intermediary services though it seemed that this segment must show a negative trend in the conditions of wide spread usage of new technologies. Insurance is a specific kind of activities, here a clients' communication with real specialists of a company cannot be $100 \%$ replaced by communication with bots. Increasing competition on the insurance market has led to expansion of the range of services within one insurance product and there are no online systems able to sell a full package of services to a client. A client who is not a specialist in this sphere cannot deal with such a product and make the decision to purchase it on their own without communicating with a representative of an insurance company.

\section{CONCLUSION}

The process of digitalization calls for revision of labor relations. In this connection it is necessary to assess opportunities to acquire new competences, to introduce the system of retraining on the State level, to constantly upgrade the system of professional standards by industries. Traditional 
labor organization processes will also change: measurement of work, methods of motivating and encouraging staff, monitoring activities of a particular employee and their influence on a company's final outcome.

Employees themselves play an important role in this environment: their ability and wish to adapt to new conditions, requirements and processes, capability to apply theory to practical use.

Attention is also given to staff members' ability to think ahead, to respond swiftly to challenges, to cooperate effectively with colleagues, to use new technologies skillfully.

Infrastructural developments on the financial market, structural changes in employment force an employee to acquire a new set of competences that may not be specific to their profession, but necessary when using new technologies.

New technologies are the main driver in the development of digital economy. They help carry out digital transmission of data. Using different file formats significantly reduces the time for submission and processing information, decreases the number of errors when working with a big data array and considerably increases employee's productivity.

Requirements for insurance professionals will only grow every year. In the context of labor relations transformation it is worth paying special attention to encouraging staff members. Insurance managers face the challenge of measuring staff development, whose responsibilities and, consequently, requirements to their knowledge and skills change now and then because of modifying conditions in their working environment. It means that a company should regularly provide their staff with retraining. Eventually, an employee becomes an object of competition between employer companies as they get a considerable set of skills and are ready to offer them to other companies.

Summarizing the research, the following should be noted. It is necessary;

- to correct some clauses of the Labor Code connected with labor relations in the process of economy digitalization;

- to develop industry-specific professional standards for insurance industry taking into account specific features of digital economy;

- to encourage employees to acquire new knowledge and key competences of digital economy;

- to improve vocational training system;

- to adapt higher education system to the requirements of digital economy.

Management decisions which, in our opinion, will help mitigate the negative effects of the digital economy in labor sphere:

- improvement of the legal and regulatory framework for labor relations;

- identification of new types of employment;
- legalization of working status of those engaged in new types of employment;

- providing conditions for highly effective and socially protected work.

The above mentioned proposals suggest clarifying certain clauses in labor legislation, developing the system of formulating and updating professional standards based on digital economy, modernizing requirements to labor organization, etc.

An important trend is growing demands on insurance professionals due to structural complexity of insurance products and increasing proportion of complex insurance products on the market.

Based on the research it is possible to conclude that development of new educational programs of complementary professional training for specialists from insurance companies is today's must. Thus, insurance specialists can study information technologies and insurance products with complex structure.

Meanwhile, trained specialists must have the following characteristics: "strategy setting; process and performance management, including innovation, with making decisions on the level of big companies or company departments; responsibility for the results of a big business and department activities; solution of professional tasks with the use of various methods and technologies, including innovations; development of new methods and technologies; understanding methodological basis of professional activities; creation of new applied knowledge in a particular field; searching for necessary information and its recourses for developing professional activities. Thus, to achieve appropriate professional level one should absorb higher education programs (magistracy, complementary professional programs) and have practical experience.

\section{References}

[1] A. Gaponenko, "Intellectual Potential of Organization", Retrieved from: http://management- gapon.blogspot.ru/2012/08/blogpost 5838. html

[2] E. Popov, "Digital economic governance features", Manag. in Russ. and Abroad, no. 2, pp. 54-61, 2017.

[3] "Online Commerce in Russia Grown to its Record P1,66 trillion", RBC channel, 03.06.2019, Retrieved from: https://www.rbc.ru/technology_ and_media/03/06/2019/5cf3dab29a79477329e7a402

[4] Labor Code of the Russian Federation. Federal Law, 30.12.2001, no. 197-FL, Retrieved from: http://www.consultant.ru/document/ cons_doc_LAW_34683/

[5] Ministry of Labor of the Russian Federation. Order no. 194, 26.03.2018, Retrieved from: https://rosmintrud.ru/docs/mintrud/orders/1290

[6] Electronic Employment Record Book. Pension Fund website, Retrieved from: http://www.pfrf.ru/etk\#info-1

[7] OECD (2014), Shifting Gear: Policy Challenges for the next 50 Years, Retrieved from: https:/www.oecd.org/eco/growth/Shifting \%20gear.pdf

[8] Declaration of International Organization of Labor about Social Justice for Fair Globalisation. Retrieved from: https://www.ilo.org/moscow/ informationresources/publications/WCMS_100193/lang--ru/index.htm

[9] Program of Cooperation between International Organisation of Labor and Russia, Retrieved from: https://www.ilo.org/moscow/news/ WCMS_535499/lang--ru/index.htm 
[10] J. Benach, A. Vives, M. Amable, C.Vanroelen, G. Tarafa, C. Muntaner, "Precarious Employment: Understanding an Emerging Social Determinant of Health", Annual Rev. of Public Health, vol. 35, pp. 229-253, 2014, Retrieved from: https://www.annualreviews.org/doi/full/10.1146/ annurevpublhealth-032013-182500

[11] Federal Service of State Statistics website. Retrieved from: http://www.gks.ru/free_doc/doc_2018/rab_sila18.pdf

[12] V. Svistunov, V. Lobachev, "Labor Relations in the Enviromment of Digital Economy”, Manag., vol. 4, no. 18, pp. 29-33, 2017.

[13] A. Fedchenko, "Transformation of Social-labor Relations in Digital Economy", Vest. Voronezh State Univer., Econ. and Manag., no. 3, pp. 91-95, 2018.

[14] The Central Bank of the Russian Federation website. "Subjects of Insurance Business", Retrieved from: https://www.cbr.ru/finmarket/ supervision/sv_insurance/

[15] Website of Accessible Public Platform for Online Monitoring Russian Labor Market Head Hunter, Retrieved from: https://stats.hh.ru.

[16] "Professional Standard Regulations", Approved by the President of Russian Union of Industrialists and Entrepreneurs, no. РП-46, 28.06.2007, Retrieved from: http://media.rspp.ru/document/1/d/a/dad 700c6ffaebe34a845fc1ccca2081c.pdf

[17] N. Kirillova, A. Tsyganov, Yu. Gryzenkova, "Training of Masters in Insurance Specialties in the Russian Federation", Perspect. of Sci. and Ed., vol. 39, no. 3, pp. 172-183, 2019. doi: 10.32744/pse.2019.3.13.

[18] "Professional Standard "Insurance Specialist". Ministry of Labor of the Russian Federation, order, 23.03.2015, no. 186H "About Approval of
Professional Standard "Insurance Specialist" (Registered in the Ministry of Justice of the Russian Federation 08.04.2015, no. 36775).

[19] "Professional standard "Insurance Broker". Ministry of Labor of the Russian Federation, order, 10.03.2015, no. 155H "About Approval of Professional Standard "Insurance Broker" (Registered in the Ministry of Justice of the Russian Federation 01.04.2015, no. 36686).

[20] A. Tsyganov, D. Brizgalov, "Digitalization of Insurance Market: Challenges, Problems, Perspectives", Econ. Taxes. Law., vol. 11, no. 2 , pp. 111-120, 2018, Retrieved from: https://doi.org/10.26794/1999849X-2018-11-2-111-120https://rosmintrud.ru/docs/mintrud/orders/1290

[21] Trends of IT Development in Insurance, Cyber-insurance, Insurance of Cyber-risks. "Clever Insurance", Retrieved from: http://www. tadviser.ru/index.php/

[22] B. Yurgens, A. Tsiganov, Job Descriptions for the Staff of Insurance Organizations. Methodical Guidelines, Moscow: Publ. house "Scientific Library", 2015, pp. 1-244.

[23] Development Strategy of Insurance Industry in the Russian Federation for 2019-2021, Retrieved from: http://www.ins-union.ru/assets/ files/2018/strategy_19_21.pdf

[24] V. Svistunov, V. Lobachev, A. Alyoshina, "Modern problems of training and retraining personel for small businesses", Manag. of Personel and intellectual resources in Russia, vol. 3, no. 30, pp. 30-35, 2017.

[25] Forysight of Education 2035, Look into the Future of Education in 2035, Retrieved from: http://changelab.tilda.ws/foresight2035 